\title{
\begin{tabular}{c|c|}
\hline Jurnal Abdimas Saintika & $\begin{array}{l}\text { e-ISSN : 2715-4424 } \\
\text { p-ISSN :2746-797X }\end{array}$ \\
\hline
\end{tabular}
}

\section{PERAN KADER KESEHATAN MENUJU \\ ERA NEW NORMAL COVID-19}

\author{
Devi Syarief $^{1^{*}}$, Nur Fadjri Nilakesuma ${ }^{2}$, Desi Wildayani ${ }^{3}$, Dewi Susilawati ${ }^{4}$, Novria \\ Hesti $^{5}$, Nur Femi ${ }^{6}$, Rania Jevira Fortuna ${ }^{7}$, Irma Isra Hayati ${ }^{8}$, Aprialda ${ }^{9}$, Yeni Gea ${ }^{10}$ \\ Program Studi S1 Kebidanan, STIKes MERCUBAKTIJAYA Padang \\ *Email : nurfadjrink@gmail.com
}

\begin{abstract}
ABSTRAK
Konsep tatanan kehidupan baru atau yang lebih dikenal dengan new normal merupakan sebuah konsep kehidupan baru dalam masa pandemi Coronavirus Disease 19 (COVID-19) dimana adanya perubahan perilaku untuk tetap menjalankan aktivitas normal dengan ditambah penerapan protokol kesehatan untuk pencegahan penularannya. Kader kesehatan adalah anggota masyarakat yang dipilih oleh masyarakat untuk membantu menangani masalah kesehatan di masyarakat. Keberadaannya sangat diperlukan dalam mensosialisasikan dan melaksanakan program-program kesehatan dalam upaya meningkatkan derajad kesehatan masyarakat. Tujuan kegiatan pengabdian masyarakat ini adalah mensosialisasikan kepada mitra tentang COVID-19, upaya pencegahannya dan bagaimana isolasi mandiri pada pasien terduga COVID-19, serta peran kader kesehatan dalam mencegah penularan COVID-19. Kegiatan dilaksanakan di hari Senin tanggal 8 Juni 2020 dari jam 13.00 WIB hingga jam 16.00 WIB secara daring melalui aplikasi Zoom dengan mengadopsi langkah-langkah action research yang terdiri dari 4 (empat) tahap, yaitu perencanaan, tindakan, observasi, dan evaluasi, refleksi . Mitra kegiatan adalah Kader Kesehatan di Kelurahan Kurao Pagang Kota Padang serta Kenagarian Pariangan dan Sungayang Kabupaten Tanah Datar. Kegiatan ini disambut antusias oleh mitra dan terdapat peningkatan pengetahuan mitra setelah penyampaian materi edukasi. Mitra diharapkan akan bisa menerapkan materi edukasi dalam kehidupan sehari-hari ataupun ketika bersama dengan ibu hamil, ibu nifas, bayi dan balita.
\end{abstract}

Kata Kunci: Peran Kader, Covid 19, New Normal

\section{ABSTRACT}

The concept of a new life order or the new normal is a concept of new life during the Coronavirus Disease 19 pandemic (COVID-19). Where there is changes in behavior to continue carrying out normal activities with added application health protocols for prevention of transmission. Health cadres are members of the community who are elected by the community to help deal with health problems in the community. Its existence is very necessary in disseminating and implementing health programs in an effort to increase the degree of public health. The purpose of this activity is to disseminate information to partners about COVID-19, prevention efforts and how to self-isolate patients suspected of COVID-19, as well the role of health cadres in preventing transmission of COVID-19. Activities held on Monday, June 8, 2020 from the hour 13.00 WIB to 16.00 WIB online via the Zoom application by adopting action research steps which consist of 4 (four) stages, namely planning, acting, observing, and evaluating, reflecting. Activity partnersare Health Cadres in Kurao Pagang Village, Padang City and Kenagarian Pariangan and Sungayang in Tanah Datar District. This activity was greeted enthusiastically by partners and there areincrease knowledge of partners after delivery of educational materials.Partners are expectedwill be able to applyeducational materialin everyday life or when together with pregnant women, postpartum mothers, babies and toddlers

Keywords: Role of Cadres, Covid 19, New Normal 


\section{Jurnal Abdimas Saintika}

Volume 3 Nomor 1 | https://jurnal.syedzasaintika.ac.id

PENDAHULUAN

Coronavirus

Disease

19

(COVID-19) merupakan penyakit yang disebabkan oleh Novel Coronavirus (2019-nCoV) atau yang kini dinamakan SARS-CoV-2 yang merupakan virus jenis baru yang belum pernah diidentifikasi sebelumnya pada manusia. Pada tanggal 30 Januari 2020, WHO menetapkan COVID-19 sebagai Public Health Emergency of International Concern (PHEIC)/ Kedaruratan Kesehatan Masyarakat Yang Meresahkan Dunia (KKMMD). Tanggal 11 Maret 2020 WHO telah menetapkan COVID-19 sebagai pandemi. Kemudian Indonesia menetapkan COVID-19 sebagai bencana nasional pada tanggal 14 Maret 2020. Kasus COVID-19 di Indonesia terus mengalami peningkatan. Menurut laporan, per 7 Juni 2020 jumlah kasus yang terkonfirmasi sudah mencapai 31.186 kasus dengan 1.851 kematian. Sumatera Barat merupakan salah satu propinsi di Indonesia yang memiliki angka kejadian cukup tinggi, yaitu 626 kasus per 7 Juni 2020 dengan 27 kematian. Kota Padang menyumbang 6 kasus per 7 Juni 2020 (Satgas Penanganan Covid-19, 2020).

Kondisi tersebut memerlukan upaya komprehensif dalam penatalaksanaan kasus dan upaya memutus rantai penularan (Kemenkes, 2020). Sebagai bencana non alam berupa wabah penyakit, maka perlu dilakukan langkah-langkah penanggulangan terpadu termasuk keterlibatan seluruh komponen masyarakat untuk pencegahan penularannya (Kemenkes RI, 2020).

Pemberdayaan masyarakat dalam pencegahan COVID-19 adalah segala upaya yang dilakukan oleh seluruh komponen masyarakat dengan menggali potensi yang dimiliki masyarakat agar berdaya dan mampu berperan serta mencegah penularan Covid-19. Salah satu komponen masyarakat yang berpotensi untuk mampu berperan serta dalam mencegah penularan COVID-19 adalah kader kesehatan (Kemenkes RI, 2020).

Saat ini merupakan masa transisi dari masa pandemi COVID-19 dengan segala pembatasan sosial berskala besar menuju suatu tatanan kehidupan baru dalam masa pandemi COVID-19. Konsep tatanan kehidupan baru atau yang lebih dikenal dengan new normal merupakan sebuah konsep kehidupan baru dalam masa pandemi COVID19 dimana ada perubahan perilaku untuk tetap menjalankan aktivitas normal namun dengan ditambah menerapkan protokol kesehatan guna mencegah terjadinya penularan COVID-19.

Kader kesehatan adalah anggota masyarakat yang dipilih oleh masyarakat untuk membantu menangani masalah kesehatan di masyarakat. Kader kesehatan merupakan mitra kerja tenaga kesehatan. Keberadaannya sangat diperlukan dalam mensosialisasikan dan melaksanakan program-program 


\section{Jurnal Abdimas Saintika}

Volume 3 Nomor $1 \mid$ https://jurnal.syedzasaintika.ac.id

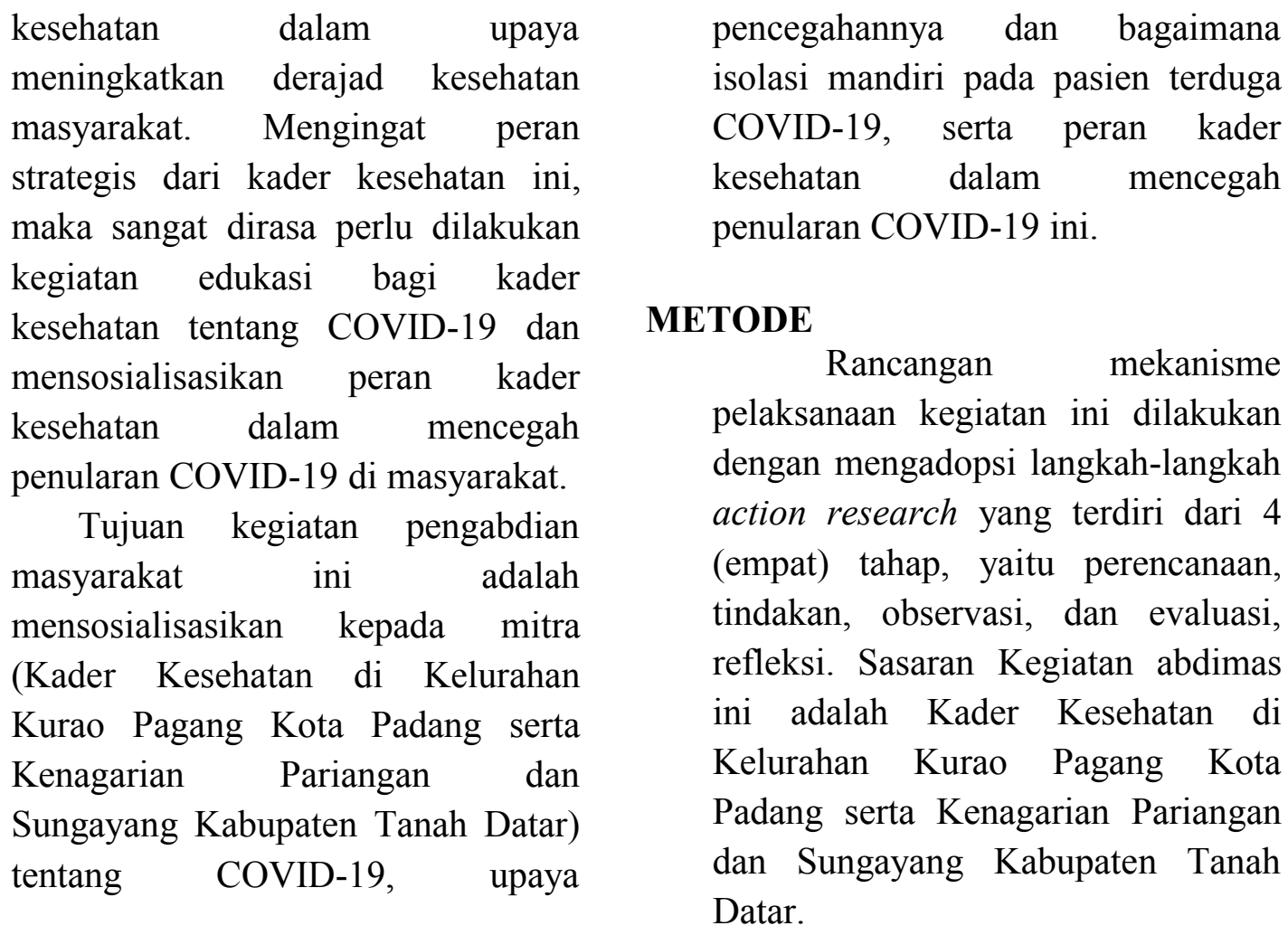

Skema Metode Kegiatan

Perencanaan :

- Koordinasi antar tim pengabdi

- Koordinasi Antar Tim Pengabdi dan mitra/

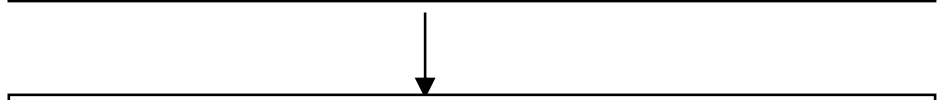

Tindakan : Pemberian Edukasi secara Virtual Meeting melalui aplikasi Zoom :

- Apa itu covid-19?

- Bagaimana cara mencegah penyebaran covid-19?

- Bagaimana cara Isolasi diri yang benar?

- Bagaimana tetap survive diera new normal covid19 ?

- Apa peran kader dalam mencegah penyebaran covid-19 di era new normal?

Observasi dan Evaluasi :

Pemberian Instrumen kuisioner Sebelum dan Sesudah Edukasi

Refleksi :

Diskusi antar tim pengabdi untuk untuk mengetahui kekurangan-kekurangan atau kelebihan-kelebihan terhadap kegiatan-kegiatan yang telah dilakukan dalam rangka menetapkan rekomendasi terhadap keberlangsungan atau pengembangan kegiatan berikutnya 


\section{Jurnal Abdimas Saintika}

\section{HASIL DAN PEMBAHASAN}

Hasil yang dicapai dalam kegiatan pengabdian kepada masyarakat adalah koordinasi dengan pihak-pihak yang terkait seperti kader, mahasiswa, program studi dan LPPM. Kegiatan ini dilaksanakan di hari Senin tanggal 8 Juni 2020 dari jam 13.00 WIB hingga jam 16.00 WIB secara daring melalui aplikasi Zoom dengan Apa itu Covid 19 yang disampaikan oleh Desi Wildayani, Bd.,M.Keb; Cara pencegahan Covid - 19 yang disampaikan oleh Novria Hesti, S.Si.T.,M.Keb; Isolasi Mandiri yang disampaikan oleh Dewi Susilawati, Bd.,M.Keb ; Adapting New Normal yang disampaikan oleh Nur Fadjri Nilakesuma Bd.,M.Keb ; Peran kader kesehatan dalam mencegah penularan Covid-19 di era new normal yang disampaikan oleh Devi Syarief, S.Si.T.,M.Keb . Mitra juga melakukan pengisian e - kuisioner sebelum dan sesuah pemberian materi penyuluhan, dan didapatkan hasil sebagai berikut :

\begin{tabular}{llcc}
\hline No & \multicolumn{1}{c}{ URAIAN } & SEBELUM & SESUDAH \\
\hline 1 & Rata - Rata & $13,67 / 15$ poin & $13,58 / 15$ poin \\
\hline 2 & Median & $14 / 15$ poin & $14 / 15$ poin \\
\hline 3 & Rentang & $13-14$ poin & $12-15$ poin \\
\hline
\end{tabular}

\begin{tabular}{l}
\multicolumn{3}{c}{ Berdasarkan data diatas, } \\
didapatkan bahwa \\
peningkatan nilai rata - rata \\
pengetahuan kader sebelum dan \\
sesudah dilakukan penyuluhan. Hal \\
ini menunjukkan rasa keingintahuan \\
kader tentang perannya dalma \\
menghadapi era new normal cukup \\
tinggi, salah satunya dapat dilihat \\
dari pertanyaan tentang penerapan
\end{tabular}

etika batuk sebagai salah satu pencegahan penularan Virus Covid 19. Sebelum dilaksanakan penyuluhan hanya 5 orang kader yang mampu menjawab dengan benar. Namun setelah diadakan penyuluhan, pengetahuan kader bertambah dengan adanya 11 orang yang menjawab dengan benar pertanyaan tersebut. 


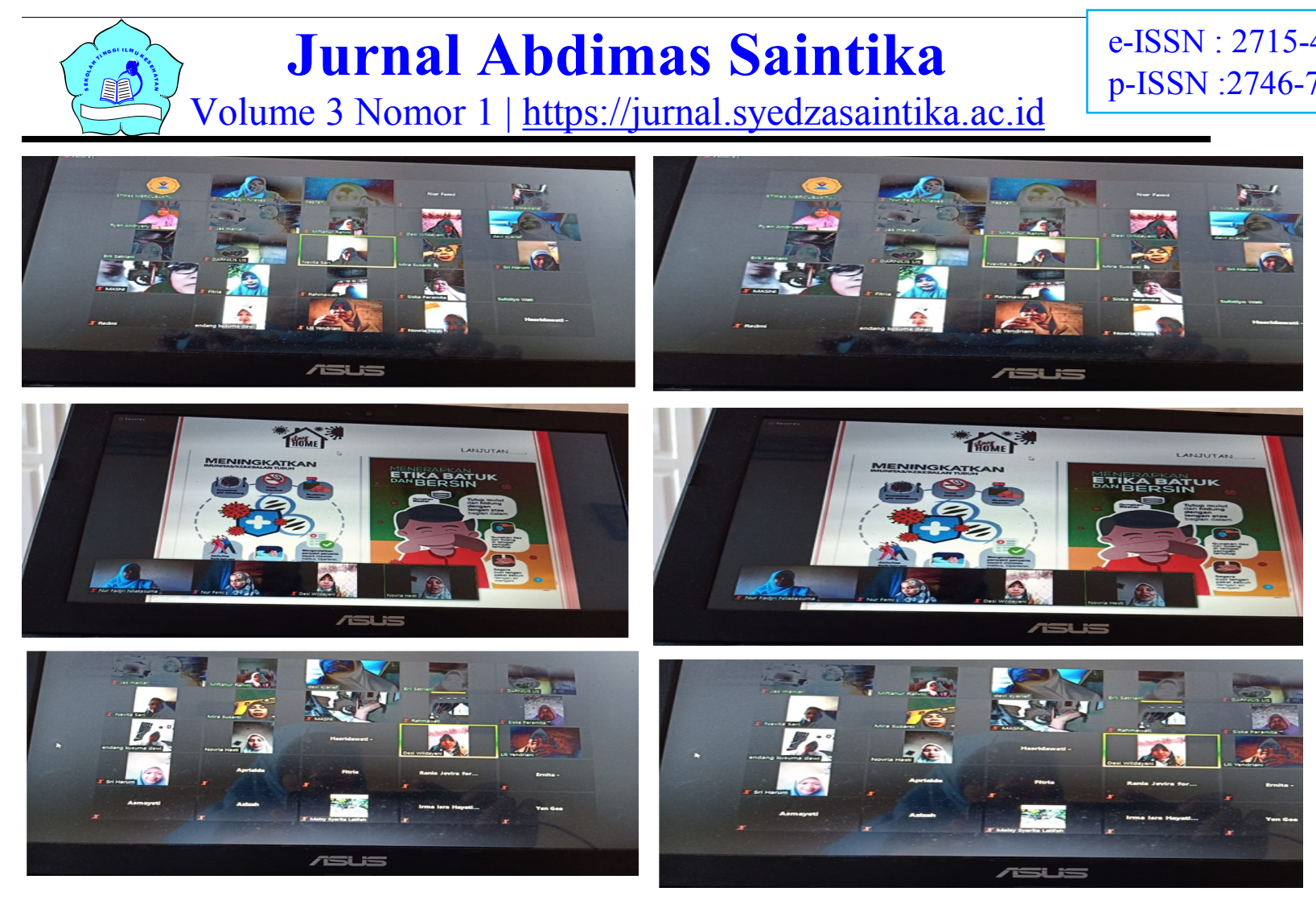

\section{Dokumentasi Kegiatan}

\section{SIMPULAN}

Kegiatan pengabdian masyarakat ini dilaksanakan secara daring melalui aplikasi Zoom Meeting. Kegiatan terlaksana dengan baik dan sesuai dengan rancangan kegiatan. Mitra sangat antusias dalam mengikuti kegiatan pengabdian, hal ini dibuktikan dengan banyaknya

\section{DAFTAR PUSTAKA}

1. Kemenkes RI. 2020. Pedoman Pemberdayaan Masyarakat dalam Pencegahan Covid-19 di RT/RW/Desa. Jakarta

2. Kemendagri, 2020. Pedoman Umum Menghadapi Pandemi Covid-19 bagi pertanyaan yang disampaikan oleh mira saat forum diskusi dan juga terjadi peningkatan pengetahuan mitra setelah penyampaian materi edukasi. Sehingga diharapkan kader sebagai kelompok peduli kesehatan ibu dan anak akan bisa menerapkan dalam kehidupan seharihari ataupun ketika bersama dengan ibu hamil, ibu nifas, bayi dan balita

Pemerintah Daerah; Pencegahan, Pengendalian, Diagnosis, Manajemen. Jakarta

3. Satgas Penanganan Covid-19. 2020. Pedoman Penanganan Cepat Medis dan Kesehatan Masyarakat Covid-19 di Indonesia. Jakarta. 